\title{
Contribution of Riverine Dissolved Inorganic Nitrogen Flux to New Production in the Coastal Northern Indian Ocean: An Assessment
}

\author{
Arvind Singh and R. Ramesh \\ Geosciences Division, Physical Research Laboratory, Navrangpura, Ahmedabad 380 009, India \\ Correspondence should be addressed to Arvind Singh, arvinds@prl.res.in
}

Received 12 October 2010; Revised 21 December 2010; Accepted 8 February 2011

Academic Editor: Swadhin Behera

Copyright ( $) 2011$ A. Singh and R. Ramesh. This is an open access article distributed under the Creative Commons Attribution License, which permits unrestricted use, distribution, and reproduction in any medium, provided the original work is properly cited.

\begin{abstract}
Rivers are known to be one of the major sources of dissolved inorganic nitrogen (DIN) to the coastal ocean and contribute to the primary productivity in the sunlit upper ocean. This study provides an analysis of DIN fluxes and its possible contribution to new production in the coastal northern Indian Ocean based on the literature data. Most of the riverine DIN flux ( $\sim 81 \%$ in the case of the Arabian Sea and $96 \%$ in the case of the Bay of Bengal) is not transported to the coastal ocean and is consumed on the course of the rivers or in the estuaries. Coastal Bay of Bengal and Arabian Sea receive $\sim 0.38 \mathrm{Tg} \mathrm{N}_{\text {year }}^{-1}\left(1 \mathrm{Tg}=10^{12} \mathrm{~g}\right)$ and $\sim 0.06 \mathrm{Tg} \mathrm{N}$ year $^{-1}$, respectively, through rivers. A large variation in the contribution of DIN through river fluxes to new production is found in both of these basins.
\end{abstract}

\section{Introduction}

Anthropogenic activities (such as deforestation and fertilizer use) have not only increased carbon dioxide $\left(\mathrm{CO}_{2}\right)$ in the earth's atmosphere, but also nitrogen on the Earth's land surface $[1,2]$. It is important to assess the sources and sinks of carbon and nitrogen as these two elements affect the earth's climate significantly and are coupled in some ways. The ocean is one of the major sinks of $\mathrm{CO}_{2}$, and its efficiency of removing $\mathrm{CO}_{2}$ by photosynthesis depends on the availability of nutrients (e.g., nitrogen, silicon, iron, phosphorus) in the sunlit upper ocean. The ocean takes up $\mathrm{CO}_{2}$ along with DIN (in a particular ratio known as Redfield Ratio, C:N : P :: 106:16:1) during photosynthesis in the photic zone (up to the depth at which the light intensity decreases to $1 \%$ of that at the surface) and the conversion rate of inorganic carbon to organic carbon is known as primary productivity. Part of this primary productivity which is supported by new nutrients (mainly nitrate), introduced from outside into the photic zone, is termed as new productivity. On an annual time scale it is approximately equal to the rate of export of organic matter to the deep from the upper ocean [3].
Primary productivity in the surface ocean is often limited due to the unavailability of nutrients such as nitrate, phosphate, and iron [3]. It is shown that the scarcity of nitrogen bearing nutrients (e.g., nitrate, nitrite, ammonia, urea, and Dissolved Organic Nitrogen (DON)) in coastal regions limits primary productivity while other nutrients are available [4]. As a result of nitrogen limitation in the surface ocean, the riverine inorganic nitrogen flux is rapidly utilized in the coast itself. This enhances the importance of coastal ecosystems, as the coastal zone (depth $<200 \mathrm{~m}$ ) occupies only $\sim 7 \%$ of the total oceanic area and $<0.5 \%$ of volume, but accounts for (i) $\sim 18-33 \%$ of oceanic biological production, (ii) $\sim 80 \%$ of organic carbon burial, (iii) $\sim 90 \%$ of sedimentary mineralization, (iv) $>50 \%$ of sedimentary denitrification, (v) $\sim 50 \%$ of $\mathrm{CaCO}_{3}$ deposition (vi) $\sim 90 \%$ of the world's fish catch, (vii) $\sim 40 \%$ of the value of the world's ecosystem services and natural capital, (viii) trapping the bulk of terrestriallyderived suspended matter, nutrients and other chemicals, including pollutants, and (ix) $\sim 40 \%$ of the world population living within $100 \mathrm{~km}$ of the coastline (16 out of 23 mega cities); that makes the coastal regions extremely vulnerable to anthropogenic perturbations [5]. Nutrients derived through rivers are partially responsible for all the above effects. 


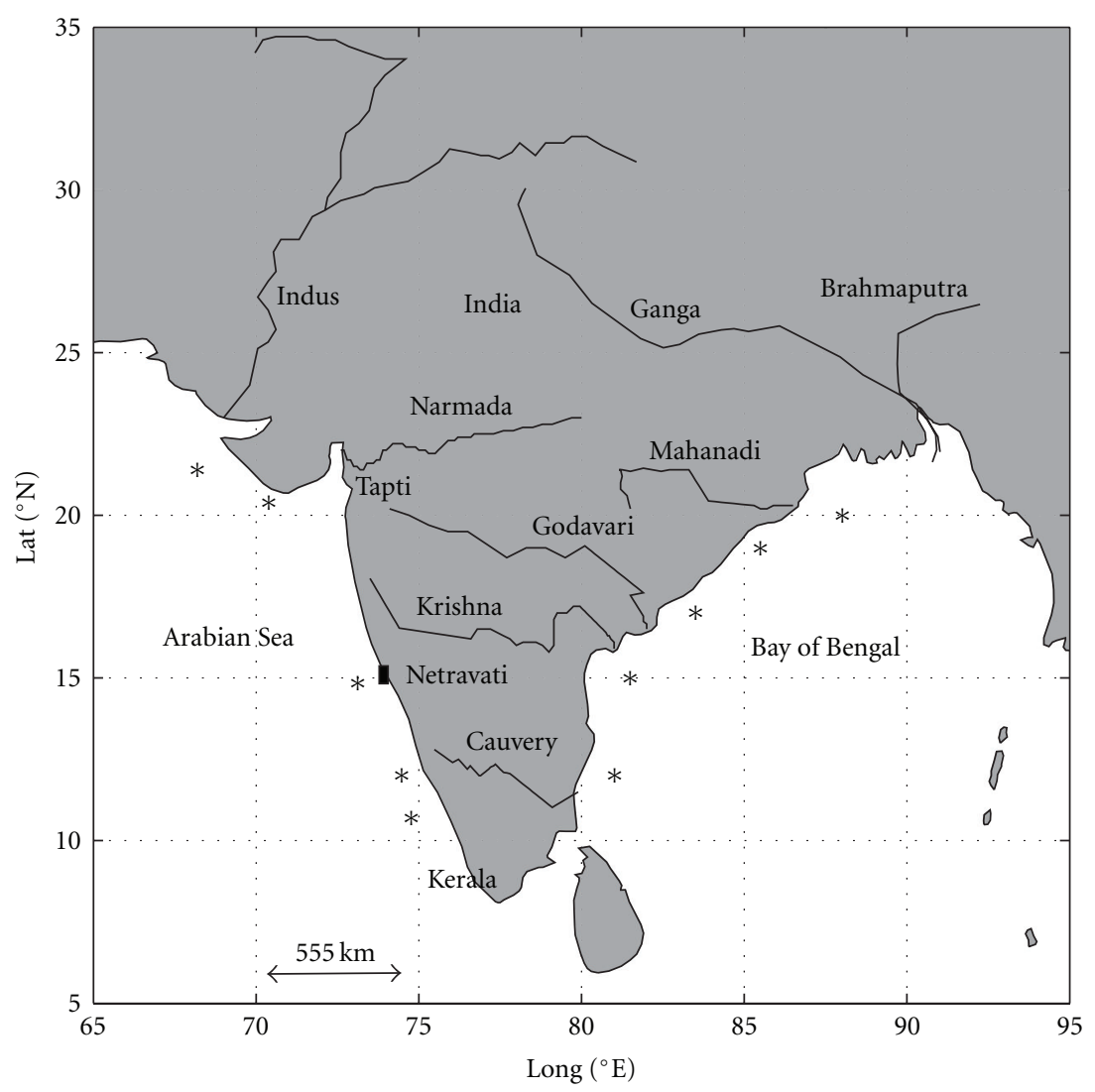

FIGURE 1: Major Indian rivers and sample locations of new production measurements in the northern Ocean (shown by asterisks $*$ ). The mouth of the Netravati is shown by a small black rectangle.

The sunlit upper ocean receives DIN through various sources, for example, upwelling, atmospheric deposition, and riverine inputs; riverine DIN flux is known to be one of the main sources to the coastal ocean and, hence, an important part of the global nitrogen cycle. It is well established that primary productivity on the ocean surface is limited by the availability of fixed inorganic nitrogen (nitrate, nitrite, and ammonium) in most oceans, including the northern Indian Ocean $[13,14]$. The role of atmospheric deposition is relatively minor $[15,16]$ and the contribution of riverine DIN flux to coastal new production in the northern Indian Ocean has not been assessed so far because of the paucity of data. With more data becoming available recently, it is possible now to assess the role of the riverine DIN flux in coastal new production.

The northern Indian Ocean provides a unique opportunity to assess the impact of DIN fluxes through both larger and smaller rivers on new production. This oceanic basin is divided into two: the Arabian Sea and Bay of Bengal (Figure 1). These regions are very different in many aspects; the eastern Arabian Sea receives relatively less water discharge $\left(0.3 \times 10^{12} \mathrm{~m}^{3} \mathrm{yr}^{-1}\right)$ relative to the Bay of Bengal from the rivers of subcontinental origin, while the western Arabian Sea is adjacent to the Arabian Desert. On the other hand, the Bay of Bengal receives a large amount of fresh water $\left(1.6 \times 10^{12} \mathrm{~m}^{3} \mathrm{yr}^{-1}\right.$, with prodigious amounts of dissolved nutrients) through rivers from the subcontinent [17, 18]. The Bay of Bengal offers a good opportunity to quantify the impacts of river discharge on new production, as some of the world's larger rivers debouch into this basin [19]. Here, we estimate the DIN transport through major rivers debouching into the northern Indian Ocean and assess the contribution of this flux to marine new production.

\section{Methods}

2.1. Subcontinent River System. Major Indian rivers are categorized into four (i) Himalayan, (ii) peninsular, (iii) coastal, and (iv) inland. The two largest rivers in northern India, that is, the Ganga (also known as the Ganges) and the Brahmaputra, flowing towards east in to the Bay of Bengal, originate in the Himalaya and rank the world's third largest river in terms of discharge, after the Amazon and the Congo (Figure 1). The Indus, a major river that flows through Pakistan to the Arabian Sea also originates in the Himalaya (Tibet). In the south, east-bound peninsular rivers that is, the Mahanadi, Godavari, Krishna, and Cauvery, originate in the Deccan plateau and flow into the Bay of Bengal. Coastal rivers such as the Netravati originate from the Western Ghats flow into the Arabian Sea. Rivers originating inland in central western India, such as the Narmada and the Tapti, discharge into the Arabian Sea [10]. 


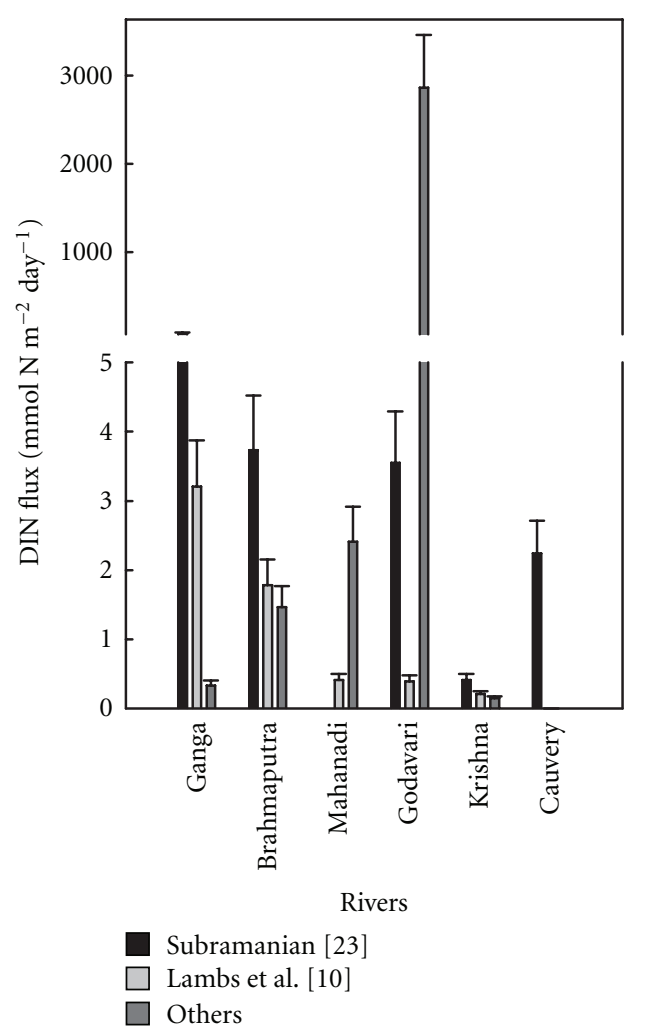

FIGURE 2: DIN fluxes to the Bay of Bengal from major Indian rivers (analysis based on the data obtained from different studies, "others" in the Figure legend include Krupadam and Anjaneyulu [4], Das et al. [6], Mukhopadhyay et al. [7], Naik et al. [8], and Singh et al. [9]). Note the break in the $x$-axis at $5 \mathrm{mmol} \mathrm{N} \mathrm{m}^{-2}$ day $^{-1}$. Errors bars indicate overall uncertainty $(21 \%)$ in flux estimations.

2.2. Calculation of DIN Flux. The DIN concentration $(C)$ and water discharge $(R)$ of rivers have been measured at several places on the river courses and estuaries/river mouths, and the data are scattered in the literature [4, 6$8,10-12,20-23]$. The areal influence (extension) of river discharge in the coastal ocean is assumed to be $1^{\circ} \times 1^{\circ}(\sim 1.2$ $\left.\times 10^{4} \mathrm{~km}^{2}\right)$; a significant amount of DIN is unlikely to be transported to the open ocean. Riverine DIN flux is derived as $F=C R A^{-1}$, where $A=$ Area of influence. Nutrients were measured using a spectrophotometer in most cases with an average accuracy of $\pm 6 \%$. Annual average river discharge $(R)$, which has large inter annual variation of $\pm 20 \%$ (http://www.grdc.sr.unh.edu/), is taken into account while calculating DIN flux. Hence, the overall uncertainty goes up to $21 \%$ as shown in the error bars in the Figures 2 and 3.

2.3. Calculation of New Production. During the past decade, the ${ }^{15} \mathrm{~N}$ tracer technique [24] has been used to measure new production in the northern Indian Ocean. In this technique, primary productivity is estimated by measuring the uptake rates of nitrate, ammonia, and urea, integrated over the photic zone (six different depths), and nitrate uptake rate alone is referred to new production. The sum of ammonia and urea uptake rates is the regenerated production. Using the Redfield ratio (C:N:P :: 106:16:1), nitrogen uptake

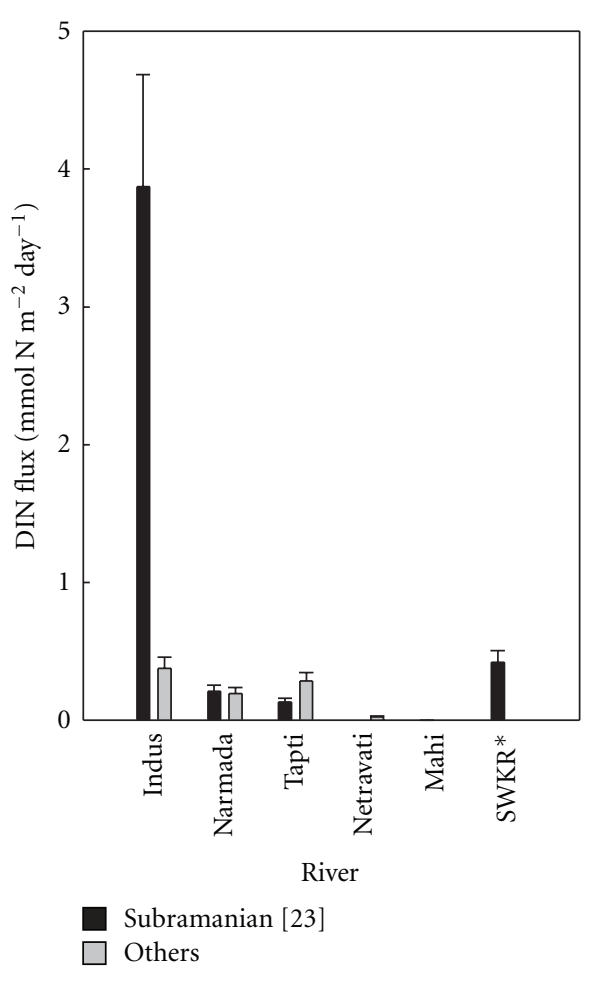

Figure 3: DIN fluxes to the Arabian Sea from major rivers that originate in the subcontinent (analysis based on the data obtained from different studies, "others" in the Figure legend include Lambs et al. [10], Karim and Veizer [11], and Zingde [12]. *Small Westflowing Kerala Rivers (average value of 15 small rivers). Errors bars indicate overall uncertainty $(21 \%)$ in flux estimations.

rates are converted to carbon uptake rates (Tables 1 and 2). Some new productivity data of the northern Indian Ocean have been published [25-29]. Figure 1 shows the locations where such new productivity measurements were performed. The overall uncertainty in the productivity measurements was less than $10 \%$. More experimental details can be found in references $[25,26]$.

\section{Results}

Table 1 shows the analysis of DIN flux (measured in head waters and some in the river course) and its estimated contribution to the new productivity. DIN flux is calculated from the mean values of DIN concentration available in the literature. The numbers for \% contribution have been calculated as (DIN flux/New production) $\times 100$, and under the hypothetical situation that all nutrients are transported efficiently to the ocean without any removal in the estuary. Listed seasons pertain to mainly to those of the DIN measurements, and new production data are obtained for times as close as possible (Tables 1 and 2). Tabulated new production data are from the ${ }^{15} \mathrm{~N}$ experiments done in the coastal areas of eastern and western India (Tables 1 and 2). New production mainly varies from $2-4 \mathrm{mmol} \mathrm{N} \mathrm{m}^{-2}$ day $^{-1}$, except in the coast near Mahanadi (where new production 
TABle 1: DIN flux $\left(\mathrm{mmolN} \mathrm{m}^{-2} \mathrm{~d}^{-1}\right)$ in the course river and its contribution (in \%) to the new production $\left(\mathrm{mmol}^{-2} \mathrm{~d}^{-1}\right)$ in the northern Indian Ocean.

\begin{tabular}{|c|c|c|c|c|c|c|}
\hline River & Season & DIN flux & $\begin{array}{c}\text { New } \\
\text { Production }^{\times}\end{array}$ & $\begin{array}{c}\text { Export } \\
\text { production } €\end{array}$ & $\%$ Contribution & References \\
\hline \multicolumn{7}{|c|}{ Rivers debouching into the Bay of Bengal } \\
\hline Ganga $^{\$}$ & Annual average & 76.41 & $2.13^{+}$ & 169 & $3587^{*}$ & {$[23,26]$} \\
\hline Ganga & April-1989 & 0.01 & 2.47 & 196 & 0.4 & {$[20,21,26]$} \\
\hline Ganga & August-2003 & 2.44 & 2.13 & 169 & $115^{*}$ & {$[22,26]$} \\
\hline Brahmaputra & Annual average & 3.74 & $2.13^{+}$ & 169 & $175^{*}$ & {$[23,26]$} \\
\hline Brahmaputra & Three years average & 1.47 & $2.13^{+}$ & 169 & 69 & {$[9,26]$} \\
\hline Mahanadi & - & $\mathrm{NA}^{\dagger}$ & 4.48 & 356 & - & {$[26]$} \\
\hline Godavari & Annual average & 3.55 & 3.87 & 308 & 92 & {$[23,26]$} \\
\hline Krishna & - do- & 0.41 & 0.17 & 14 & $243^{*}$ & {$[23,26]$} \\
\hline Krishna & September-2002 & 0.15 & 0.17 & 14 & 88 & {$[6,21,26]$} \\
\hline Cauvery & Annual average & 2.24 & 0.63 & 50 & $356^{*}$ & {$[23,26]$} \\
\hline \multicolumn{7}{|c|}{ Rivers debouching into the Arabian Sea } \\
\hline Indus & Annual average & 3.87 & 2.48 & 197 & $156^{*}$ & {$[23,25]$} \\
\hline Indus & - do- & 0.83 & 2.48 & 197 & 34 & {$[11,25]$} \\
\hline Narmada & -do- & 0.21 & 4.25 & 338 & 5 & {$[23,25]$} \\
\hline Netravati & - & $\mathrm{NA}^{\dagger}$ & 0.46 & 37 & - & [27] \\
\hline Mahi & -do- & 0.001 & - & - & - & [23] \\
\hline $\mathrm{SWKR}^{+}$ & -do- & 0.42 & 1.56 & 124 & 27 & {$[23,27]$} \\
\hline
\end{tabular}

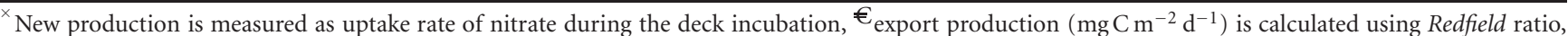
\$also known as Ganges, ${ }^{+}$new production near the Ganga and Brahmaputra is taken to be the same as they debouch at the same place, ${ }^{\dagger}$ data not available, * high values can be attributed to either the eutrophication of the coastal ocean or where much of the DIN could be removed prior to discharge into the coastal ocean, and ${ }^{+}$small west-flowing Kerala Rivers (average of 15 rivers).

is $\sim 11 \mathrm{mmol} \mathrm{N} \mathrm{m}^{-2} \mathrm{day}^{-1}$, equivalent export production $\sim$ $\left.850 \mathrm{mg} \mathrm{C} \mathrm{m}^{-2} \mathrm{day}^{-1}\right)$. In the case of measurements done on the river course, a calculated contribution exceeding $100 \%$ (represents eutrophication condition) implies that DIN gets removed on the land or in the estuary. Possible reasons could be DIN uptake during primary production in the estuary and denitrification (an anaerobic microbial process that reduces nitrate to decompose organic matter). Such nitrate reduction reactions occur in the water column of high turbidity $[30,31]$ and in the sediments.

As major Indian rivers debouch into the Bay of Bengal, a higher DIN flux is expected in the Bay than the Arabian Sea, which is consistent with our analysis (Figures 2 and 3 ). The maximum and minimum DIN fluxes are observed in the Ganga, and so is its contribution to the new production. Variations in data (mainly DIN flux) large (Table 1). Subramanian [23] reported higher DIN concentration in the Ganga and the Cauvery rivers, which yields a higher flux and hence the unusual high contribution to the new production (Table 1 and Figure 2).

\section{Discussions}

4.1. Bay of Bengal. Our analysis based on data reported by Subramanian [23] shows that the Bay of Bengal receives $\sim 9 \mathrm{Tg} \mathrm{N}_{\text {year }}{ }^{-1}$ through major Indian rivers to which Ganga alone contributes $\sim 5 \mathrm{Tg} \mathrm{N}_{\text {year }}^{-1}\left(9 \mathrm{Tg} \mathrm{N}_{\text {year }}{ }^{-1}\right.$ also includes the $3 \mathrm{Tg} \mathrm{N}_{\text {year }}{ }^{-1}$ transport through Padma, Meghna, and other tributaries of the Ganga, which debouch into the Bay via Bangladesh). Most of the agricultural activities are supported by the Ganga waters in the northern India. Fertilizer use in the fields around the Ganga basin has been increasing [23]. This could have led to the large nitrate transport through the Ganga. All other rivers such as Godavari and Krishna have a minor DIN transport, that is, $<1 \mathrm{Tg} \mathrm{N}$ year ${ }^{-1}$. Analysis based on the data presented by Lambs et al. [10] suggests that the Bay receives $0.4 \mathrm{Tg} \mathrm{N}$ year $^{-1}$, and $50 \%$ of this amount is transported through the Ganga. We conclude from our analysis that a major fraction of DIN is carried by the Ganga, though the two studies [10,23] sampled different stations: those of Subramanian [23] are on the river course while those of Lambs et al. [10] are at the river mouth. It appears that $96 \%$ of this DIN does not reach the Bay and is consumed on the way.

DIN concentration measurements in the river course show that the contribution of riverine DIN flux to new production is always more than $100 \%$ except for a few, such as for April 1989, which only show a $0.37 \%$ contribution from the Ganga (Table 1). The Ganga also shows an abnormally high contribution, that is, $3,587 \%$ to new production in the adjacent area, from the data based on another report (Table 1). This must be interpreted in terms of eutrophication of coastal waters.

Estuarine measurements show larger fluxes in the Mahanadi during October-November 2004 and 2005, but the contribution of this flux to marine new production is not 
TABLE 2: DIN flux ( $\mathrm{mmol} \mathrm{N} \mathrm{m}^{-2} \mathrm{~d}^{-1}$ ) measured in the rivermouths/estuary and its contribution to the new production ( $\mathrm{mmol}^{-2} \mathrm{~d}^{-1}$ ) in the northern Indian Ocean.

\begin{tabular}{|c|c|c|c|c|c|c|}
\hline River & Season & DIN flux & $\begin{array}{c}\text { New } \\
\text { Production }^{\times}\end{array}$ & $\begin{array}{c}\text { Export } \\
\text { production } €\end{array}$ & $\%$ Contribution & References \\
\hline \multicolumn{7}{|c|}{ Rivers debouching into the Bay of Bengal } \\
\hline Ganga & $\begin{array}{l}\text { February-May } \\
\text { 1999-2001 }\end{array}$ & 0.09 & 2.47 & 196 & 4 & {$[7,26]$} \\
\hline Ganga & $\begin{array}{l}\text { June-September } \\
\text { 1999-2001 }\end{array}$ & 0.46 & 2.13 & 169 & 22 & {$[7,26]$} \\
\hline Ganga & August 2001 & 3.20 & 2.13 & 169 & $150^{*}$ & {$[10,26]$} \\
\hline Brahmaputra & -do- & 1.78 & 2.23 & 177 & 84 & {$[10,26]$} \\
\hline Mahanadi & -do- & 0.41 & 4.48 & 356 & 9 & {$[10,26]$} \\
\hline Mahanadi & $\begin{array}{l}\text { May-June } \\
\text { 2004-2005 }\end{array}$ & 1.87 & 10.68 & 849 & 18 & {$[8,26]$} \\
\hline Mahanadi & $\begin{array}{l}\text { October- } \\
\text { November } \\
2004-2005\end{array}$ & 3.47 & 4.48 & 356 & 77 & {$[8,26]$} \\
\hline Godavari & August 2001 & 0.40 & 3.87 & 308 & 10 & {$[10,26]$} \\
\hline Godavari & January 1996 & 306 & 4.35 & 346 & $7024^{*}$ & {$[4,26]$} \\
\hline Godavari & July 1996 & 5420 & 3.87 & 308 & $140041^{*}$ & {$[4,26]$} \\
\hline Krishna & August 2001 & 0.21 & 0.17 & 14 & $124^{*}$ & {$[10,26]$} \\
\hline Cauveri & -do- & 0.004 & 0.63 & 50 & 0.7 & {$[10,26]$} \\
\hline \multicolumn{7}{|c|}{ Rivers debouching into the Arabian Sea } \\
\hline Indus & Annual average & 0.38 & 2.48 & 197 & 15 & {$[11,25]$} \\
\hline Narmada & August 2001 & 0.38 & 4.25 & 338 & 9 & {$[10,25]$} \\
\hline Narmada & March-May 1979 & 0.01 & 4.25 & 338 & 1 & {$[12,25]$} \\
\hline Narmada & February-1995 & 0.02 & 4.25 & 338 & 3 & {$[12,25]$} \\
\hline Narmada & March-1997 & 0.03 & 4.25 & 338 & 5 & {$[12,25]$} \\
\hline Netravati & August 2001 & 0.03 & 5.64 & 448 & 0.5 & {$[10,27]$} \\
\hline
\end{tabular}

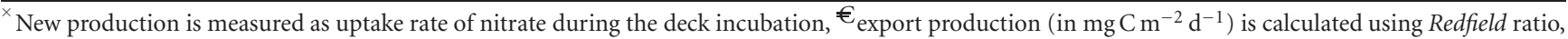
and $*$ high values can be attributed to either the eutrophication of the coastal ocean or where much of the DIN could be removed prior to discharge into the coastal ocean.

the maximum from this river, but from the Ganga during August 2001 (Table 2). One of the largest Indian rivers, Brahmaputra, shows a higher contribution (84\%) to new production. The Cauvery contributes a minimum $(0.7 \%)$ to new production (Table 2), although it passes through vast areas of rice cultivation, with an excessive of nitrogenous fertilizers [23]. This is likely because most of the Cauvery water is used for irrigation, and only $5 \%$ of the river water escapes to the ocean, which could reduce DIN fluxes and hence a lesser contribution to marine new productivity [10].

4.2. Arabian Sea. Our estimation based on data reported by Subramanian [23] shows that the Arabian Sea receives $0.3 \mathrm{TgN}$ year $^{-1}$ (if the flux in west-flowing rivers in north of Kerala are not excluded, it is abnormally large that is, $4.3 \mathrm{Tg} \mathrm{N}^{-1} \mathrm{yer}^{-1}$ ) and the Indus alone contributes $0.2 \mathrm{TgN}$ year $^{-1}$ (DIN transport through other rivers is not statistically significant). Analysis based on the data presented by Lambs et al. [10] and Karim and Veizer [11] suggests an order of magnitude lesser values: that is, the Arabian Sea receives $0.07 \mathrm{Tg} \mathrm{N}_{\text {year }}{ }^{-1}$ and the Indus contribution $0.02 \mathrm{Tg} \mathrm{N}_{\mathrm{N}} \mathrm{ear}^{-1}$. Sampling locations by Subramanian [23] are on the river course while the data of Lambs et al. [10] and Karim and Veizer [11] are from river mouths. This reveals that $81 \%$ of this DIN does not reach the Arabian Sea and is consumed on the way (mostly in the estuaries).

Unlike the rivers debouching into the Bay, here rivers seldom show higher than $100 \%$ contribution to the new production except the Indus (Table 1). Estimates based on estuarine DIN concentrations show that although the Indus and the Narmada rivers transport equal amount of DIN, the marine new production is more in the coast near Narmada and hence its contribution to new production is less (Table 2).

Analysis of nutrient discharge through rivers to the Arabian Sea and the Bay of Bengal shows that most of the DIN is transported through rivers of Himalayan origin and most of it is consumed on the way because of the longer river courses. Globally $4-5 \%$ to the $\mathrm{N}$ input to agricultural systems is transported to the coastal seas [32]. Our analysis also supports this and is in agreement with the conclusion of Bouwman et al. [32] that most of the DIN is removed on the land before it reaches the ocean because part of the nitrogen is first reduced by crop removal, and the remaining is reduced by denitrification in the soil, followed by denitrification in 
groundwater systems. Field experiments may help quantify these losses.

4.3. Riverine Flux Versus Coastal Upwelling. Intense upwelling during summer (June-September) and vertical mixing in winter (December-February) make the Arabian Sea the more productive basin $[28,29,33]$. On the other hand, river discharge stratifies the surface Bay of Bengal and inhibits upwelling [34, and references therein]. As a result, the Arabian Sea is more productive relative to the Bay. However, new production is comparable in both basins (Tables 1 and 2). Sediment trap observations also suggest comparable organic matter transport to the deep in both basins [35]. Costal upwelling, driven by local winds, is not strong enough to explain the higher new production in the Bay of Bengal $[36,37]$. Eddies have been suggested to be one of the possible sources of nutrients in the Bay of Bengal [37, 38]. We propose the riverine DIN flux to be a potential factor for the higher new productivity in the coastal Bay, though most of the riverine nutrients are removed in the estuaries. Nutrients produced through remineralisation of organic matter in the estuary may be transported into the ocean and thus could enhance new productivity.

Costal upwelling introduces $65 \times 10^{10} \mathrm{~m}^{3}$ water from the deep to the surface in the Arabian Sea during the summer monsoon [39]. Assuming that this water (having a nitrate concentration of $\sim 5.56 \mu \mathrm{M})$ is spread over $1^{\circ} \times$ $1^{\circ}$ area, $2.44 \mathrm{mmol} \mathrm{N} \mathrm{m}^{-2} \mathrm{~d}^{-1}$ is brought up during intense upwelling. Higher coastal new production (e.g., new production is $4.25 \mathrm{mmol} \mathrm{N} \mathrm{m}^{-2} \mathrm{~d}^{-1}$ where the Narmada debouches) suggests a significant contribution from the rivers even during an intense upwelling period in the Arabian Sea.

4.4. Submarine Groundwater Discharge. Submarine groundwater discharges nutrients into the ocean. Preliminary and limited results from a costal site in southern India reported 86.4-142 $\mu \mathrm{M}$ nitrate in the submarine groundwater discharge [40]. Groundwater flux is $2,300-23,000 \mathrm{~m}^{3} \mathrm{~s}^{-1}$, rarely comparable to the riverine flux [41]. Since nitrate is quite low in groundwater, this discharge does not contribute significantly to marine new production $(<1 \%)$. In such cases, where groundwater discharge and upwelling are not significant, the riverine flux seems to be contributing significantly to higher marine new production (e.g., in the Bay of Bengal).

4.5. Changes in the Redfield Ratio and Biodiversity. Sea surface water micro-organisms take up $\mathrm{C}: \mathrm{N}: \mathrm{P}$ in a particular ratio which is known as Redfield Ratio. Duce et al. [15] suggested that phosphorous concentration in the surface ocean is not significantly affected by anthropogenic activity and hence nitrogen fluxes alone are likely to enhance the $\mathrm{N}: \mathrm{P}$ in the surface sea water. As most of the new production in the coastal ocean is supported by riverine DIN fluxes, this may result in increasing dissolved N:P. Any change in the Redfield ratio causes a change in the ecosystem composition, which may have positive/negative influence on the marine environments [42]. It is shown recently that a major part of nitrogen is also lost in its organic form [43], that is, DON. Unavailability of DON data precludes the assessment of its contribution to coastal new production. Quantification of DON fluxes along with DIN may improve estimates of nitrogen loss through rivers and its contribution to new production.

\section{Conclusion}

This study synthesizes important information needed to understand the riverine DIN fluxes (the nitrogen cycle) and their contribution to new production. We infer that a major fraction of the DIN transported through Indian rivers is removed on the Earth's land surface and in the estuaries; however, a significant contribution ( $\sim 13 \%$, geometric mean $)$ of this nitrogen to coastal new production is observed. The contribution of riverine DIN to coastal new production is higher in the Bay of Bengal than in the Arabian Sea. Assessing riverine DON fluxes will provide better insight on nitrogen inputs.

\section{Acknowledgment}

The authors thank ISRO-GBP for funding.

\section{References}

[1] S. Solomon, D. Qin, M. Manning et al., Eds., Fourth Assessment Report of the Intergovernmental Panel on Climate Change, Cambridge University Press, Cambridge, UK, 2007.

[2] N. Gruber and J. N. Galloway, "An Earth-system perspective of the global nitrogen cycle," Nature, vol. 451, no. 7176, pp. 293-296, 2008.

[3] R. W. Eppley and B. J. Peterson, "Particulate organic matter flux and planktonic new production in the deep ocean," Nature, vol. 282, no. 5740, pp. 677-680, 1979.

[4] R. J. Krupadam and Y. Anjaneyulu, "Cycling of nutrients in Gautami-Godavari Estuarine Ecosystem, Bay of BengalEast Coast of India," Research Journal of Chemistry and Environment, vol. 4, pp. 55-70, 2000.

[5] J.-P. Gattuso, S. V. Smith, and J. E. Duffy, "Coastal zone," in Encyclopedia of Earth, C. J. Cleveland, Ed., Environmental Information Coalition, National Council for Science and the Environment, Washington, DC, USA, 2007.

[6] A. Das, S. Krishnaswami, M. M. Sarin, and K. Pande, "Chemical weathering in the Krishna basin and Western ghats of the Deccan Traps, India: rates of basalt weathering and their controls," Geochimica et Cosmochimica Acta, vol. 69, no. 8, pp. 2067-2084, 2005.

[7] S. K. Mukhopadhyay, H. Biswas, T. K. De, and T. K. Jana, "Fluxes of nutrients from the tropical River Hooghly at the land-ocean boundary of Sundarbans, NE Coast of Bay of Bengal, India," Journal of Marine Systems, vol. 62, no. 1-2, pp. 9-21, 2006.

[8] S. Naik, B. C. Acharya, and A. Mohapatra, "Seasonal variations of phytoplankton in Mahanadi estuary, east coast of India," Indian Journal of Marine Sciences, vol. 38, no. 2, pp. 184-190, 2009. 
[9] S. K. Singh, M. M. Sarin, and C. France-Lanord, "Chemical erosion in the eastern Himalaya: major ion composition of the Brahmaputra and $\delta \mathrm{C}$ of dissolved inorganic carbon," Geochimica et Cosmochimica Acta, vol. 69, no. 14, pp. 35733588, 2005.

[10] L. Lambs, K. Balakrishna, F. Brunet, and J. L. Probst, "Oxygen and hydrogen isotopic composition of major Indian rivers: a first global assessment," Hydrological Processes, vol. 19, no. 17, pp. 3345-3355, 2005.

[11] A. Karim and J. Veizer, "Weathering processes in the Indus River Basin: implications from riverine carbon, sulfur, oxygen, and strontium isotopes," Chemical Geology, vol. 170, no. 1-4, pp. 153-177, 2000.

[12] M. D. Zingde, "Inputs into the oceans from land/rivers and pollution,” in Oceanology, H. K. Gupta, Ed., Universities Press, 2005.

[13] W. S. Broecker, Chemical Oceanography, Harcourt Brace Jovanovich, New York, NY, USA, 1974.

[14] P. G. Falkowski, "Evolution of the nitrogen cycle and its influence on the biological sequestration of $\mathrm{CO}_{2}$ in the ocean," Nature, vol. 387, no. 6630, pp. 272-275, 1997.

[15] R. A. Duce, J. LaRoche, K. Altieri et al., "Impacts of atmospheric anthropogenic nitrogen on the open ocean," Science, vol. 320, no. 5878, pp. 893-897, 2008.

[16] A. Singh, N. Gandhi, and R. Ramesh, "Role of atmospheric deposition in new productivity in the northern Indian Ocean," Journal of Geophysical Research, to be submitted after revision.

[17] V. Subramanian, "Sediment load of Indian rivers," Current Science, vol. 64, pp. 928-930, 1993.

[18] T. G. Prasad, "Annual and seasonal mean buoyancy fluxes for the tropical Indian Ocean," Current Science, vol. 73, no. 8, pp. 667-674, 1997.

[19] K. Wyrtki, Oceanographic Atlas of the International Indian Ocean Expedition, National Science Foundation, Washington, DC, USA, 1971.

[20] M. M. Sarin, S. Krishnaswami, J. R. Trivedi, and K. K. Sharma, "Major ion chemistry of the Ganga source waters: Weathering in the high altitude Himalaya," Proceedings of the Indian Academy of Sciences_Earth and Planetary Sciences, vol. 101, no. 1, pp. 89-98, 1992.

[21] S. Krishnaswami and S. K. Singh, "Chemical weathering in the river basins of the Himalaya, India," Current Science, vol. 89, no. 5, pp. 841-849, 2005.

[22] M. J. Bickle, H. J. Chapman, J. Bunbury et al., "Relative contributions of silicate and carbonate rocks to riverine Sr fluxes in the headwaters of the Ganges," Geochimica et Cosmochimica Acta, vol. 69, no. 9, pp. 2221-2240, 2005.

[23] V. Subramanian, "Nitrogen transport by rivers of south Asia," Current Science, vol. 94, no. 11, pp. 1413-1418, 2008.

[24] R. C. Dugdale and J. J. Goering, "Uptake of new and regenerated forms of nitrogen in primary productivity," Limnology \& Oceanography, vol. 12, pp. 196-206, 1967.

[25] S. Kumar and R. Ramesh, "Productivity measurements in the Bay of Bengal using $15 \mathrm{~N}$ tracer: implications to the global carbon cycle," Indian Journal of Marine Sciences, vol. 34, no. 2, pp. 153-162, 2005.

[26] S. Kumar, R. Ramesh, S. Sardesai, and M. S. Sheshshayee, "High new production in the Bay of Bengal: possible causes and implications," Geophysical Research Letters, vol. 31, no. 18, Article ID L18304, 4 pages, 2004.

[27] S. Prakash, R. Ramesh, M. S. Sheshshayee, R. M. Dwivedi, and M. Raman, "Quantification of new production during a winter Noctiluca scintillans bloom in the Arabian Sea," Geophysical Research Letters, vol. 35, no. 8, Article ID L08604, 2008.
[28] S. Kumar, R. Ramesh, R. M. Dwivedi, M. Raman, M. S. Sheshshayee, and W. D'Souza, "Nitrogen uptake in the northeastern Arabian Sea during winter cooling," International Journal of Oceanography, vol. 2010, Article ID 819029, 11 pages, 2010.

[29] N. Gandhi, R. Ramesh, R. Srivastava, M. S. Sheshshayee, R. M. Dwivedi, and M. Raman, "Nitrogen uptake rates during spring in the NE Arabian Sea," International Journal of Oceanography, vol. 2010, Article ID 127493, 10 pages, 2010.

[30] N. J. P. Owens, "Estuarine nitrification: a naturally occurring fluidized bed reaction?" Estuarine, Coastal and Shelf Science, vol. 22, no. 1, pp. 31-44, 1986.

[31] T. Jickells, "External inputs as a contributor to eutrophication problems," Journal of Sea Research, vol. 54, no. 1, pp. 58-69, 2005.

[32] A. F. Bouwman, G. Van Drecht, J. M. Knoop, A. H. W. Beusen, and C. R. Meinardi, "Exploring changes in river nitrogen export to the world's oceans," Global Biogeochemical Cycles, vol. 19, no. 1, pp. 1-14, 2005.

[33] S. Prakash and R. Ramesh, "Is the Arabian Sea getting more productive?" Current Science, vol. 92, no. 5, pp. 667-671, 2007.

[34] A. Singh, R. A. Jani, and R. Ramesh, "Spatiotemporal variations of the $\delta^{18} \mathrm{O}$-salinity relation in the northern Indian Ocean," Deep-Sea Research Part I, vol. 57, no. 11, pp. 1422-1431, 2010.

[35] V. Ramaswamy and R. R. Nair, "Fluxes of material in the Arabian Sea and Bay of Bengal-sediment trap studies," Proceedings of the Indian Academy of Sciences-Earth and Planetary Sciences, vol. 103, no. 2, pp. 189-210, 1994.

[36] S. R. Shetye, S. S. C. Shenoi, A. D. Gouveia, G. S. Michael, D. Sundar, and G. Nampoothiri, "Wind-driven coastal upwelling along the western boundary of the Bay of Bengal during the southwest monsoon," Continental Shelf Research, vol. 11, no. 11, pp. 1397-1408, 1991.

[37] S. P. Kumar, M. Nuncio, J. Narvekar et al., "Are eddies nature's trigger to enhance biological productivity in the Bay of Bengal?" Geophysical Research Letters, vol. 31, no. 7, Article ID L07309, 5 pages, 2004.

[38] N. Gandhi, A. Singh, and R. Ramesh, "Nitrogen sources for new production in the NE Indian Ocean," Advances in Geosciences, vol. 24, pp. 55-67, 2010.

[39] T. Rixen, B. Haake, and V. Ittekkot, "Sedimentation in the western Arabian Sea the role of coastal and open-ocean upwelling," Deep-Sea Research Part II, vol. 47, no. 9-11, pp. 2155-2178, 2000.

[40] B. L. K. Somayajulu, Nuclear and Isotopic Techniques for the Characterization of Submarine Groundwater Discharge in Coastal Zones, IAEA, Vienna, Austria, 2008.

[41] W. S. Moore, "High fluxes of radium and barium from the mouth of the Ganges-Brahmaputra River during low river discharge suggest a large groundwater source," Earth and Planetary Science Letters, vol. 150, no. 1-2, pp. 141-150, 1997.

[42] H. W. Paerl, "Nuisance phytoplankton blooms in coastal, estuarine, and inland waters," Limnology \& Oceanography, vol. 33, no. 4, pp. 823-847, 1988.

[43] S. S. Perakis and L. O. Hedin, "Nitrogen loss from unpolluted South American forests mainly via dissolved organic compounds," Nature, vol. 415, no. 6870, pp. 416-419, 2002. 

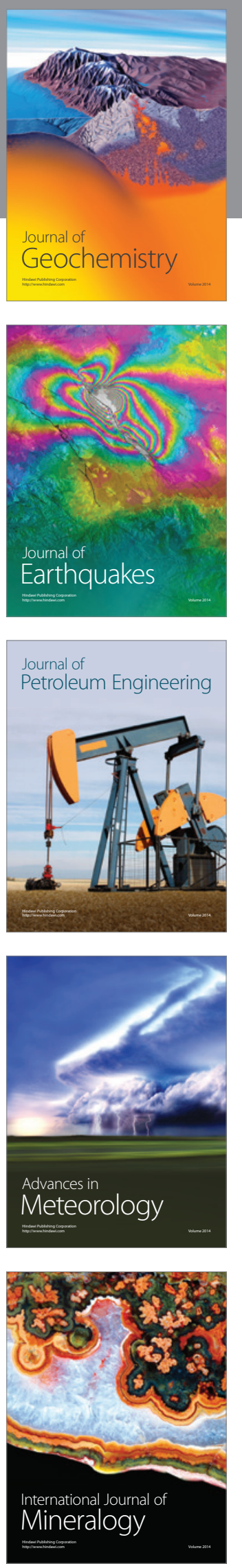
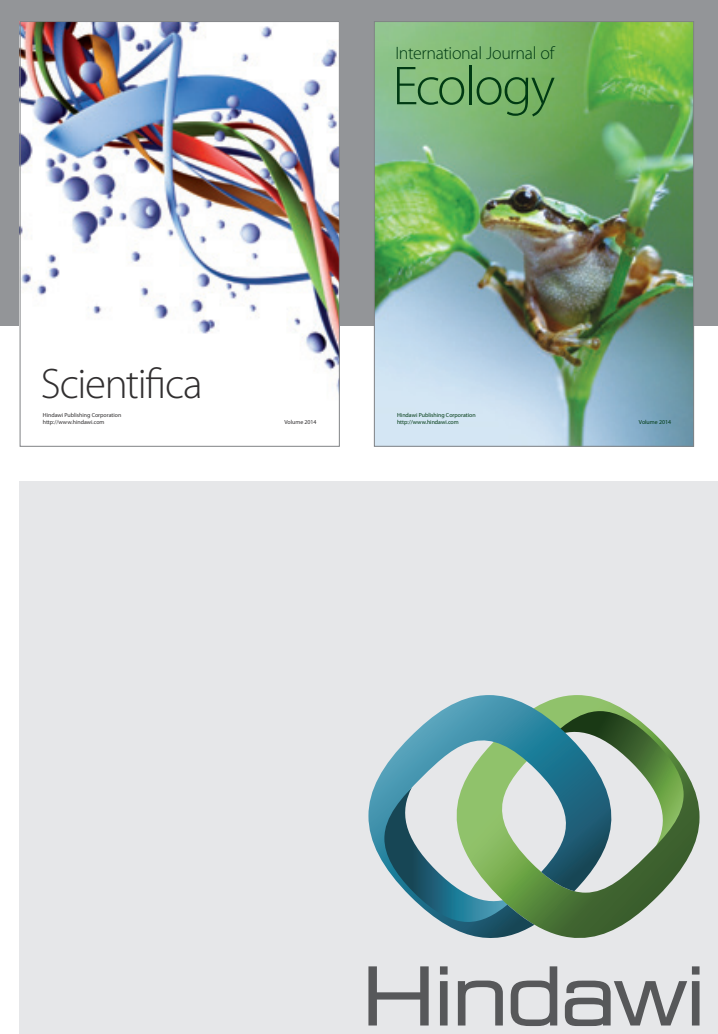

Submit your manuscripts at http://www.hindawi.com
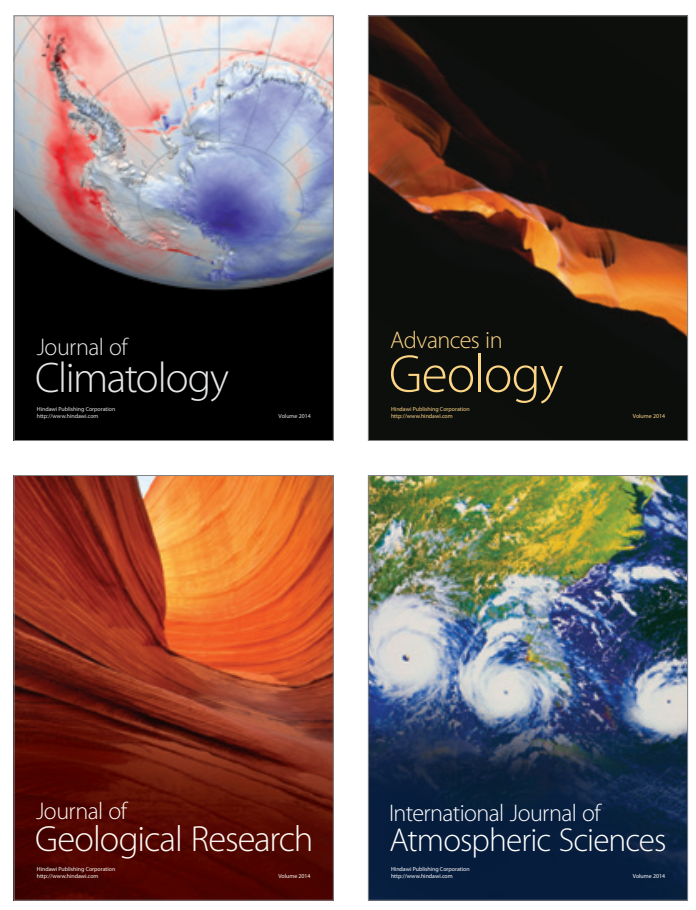
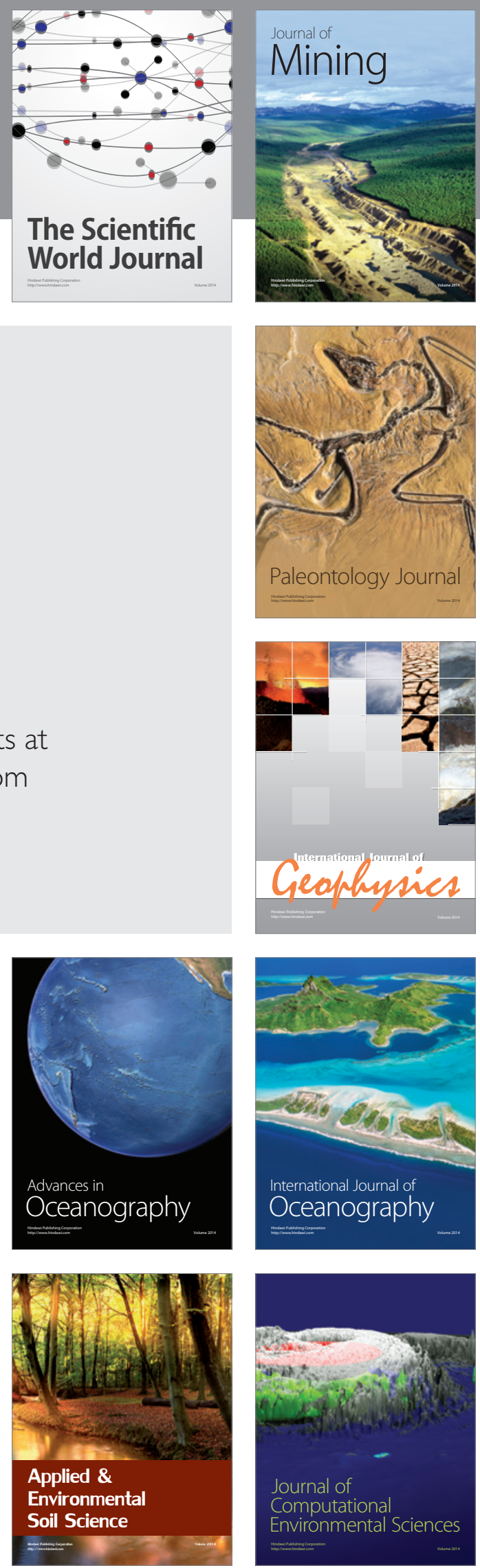